\title{
ПРИМЕНА МОБИЛНИХ АПЛИКАЦИЈА У БИБЛИОТЕКАМА СРБИЈЕ
}

Сажетак: Овај рад представља кратак увод о технологији мобилне апликације и њеној употреби у библиотечким услугама. У раду се такође испитују врсте мобилних апликација и оне специфичне апликације доступне библиотекарима. Укратко су описане истакнуте карактеристике апликација, као и предности и потенцијални недостаци. Аутор покушава да примети важна разматрања, као што су безбедност, поузданост, доступност и цена, којих професионалци у библиотеци морају бити свесни пре употребе мобилних апликација. Мобилне апликације за приступ библиотекама осим што омогућују приступ библиотечким фондовима, омогућавају и напредније функције, као што је позајмљивање књига, претраживање архива и др. За библиотечке мобилне апликације још кажу да су то „библиотеке које стају у џеп”. Код нас је мало библиотека које имају развијену мобилну апликацију, за разлику од оних у свету. У раду ћемо представити очекивања и могућности коришћења библиотечких мобилних апликације код нас

Кључне речи: технологија, мобилни телефони, мобилне апликације, библиотеке, библиотечке услуге, књиге, публикације.

\section{Увод}

Откако су персонални рачунари постали доступни у домовима и школама, развој образовне технологије напредовао је убрзаним темпом. С напретком у мобилној технологији и порастом употребе паметних телефона, захваљујући интернету, људи користе предност повезивања са подацима где год да се налазе. ${ }^{1}$ Појавом првих паметних телефона, условљених 
изградњом $\mathrm{IOS}$ и Андроид оперативних система, од 2007. године, дошло је до праве револуције у употреби и масовном коришћењу мобилних уређаја. Сада мобилни телефони нису само за позивање: може се приступити вишеструким апликацијама као што су електронска пошта, разни претраживачи, видео-позиви, игрице и др. Предвиђања великог броја аутора су остварена, а многа чак и надмашена, када је реч о процени броја корисника паметних телефона и мобилних апликација. ${ }^{2}$

Стварање библиотечке апликације која омогућава корисницима приступ садржајима библиотеке, преглед њихових библиотечких налога или чак претраживање база података, лакше је него што већина људи мисли. Овај рад описује мобилне апликације и стратешке циљеве, као и примере библиотечких апликација. Мобилне апликације могу помоћи корисницима библиотека на тај начин што им је двадесет четири сата омогућен приступ библиотечким е-ресурсима, ОПАК-у, библиотечком прегледу, вестима и мултимедијалним материјалима за учење заједно са више канала за интеракцију итд. ${ }^{3}$

\section{Карактеристике мобилних апликација}

Мобилна апликација, или само апликација, у ствари је софтвер који обично ради на мобилном уређају. Карактеристике библиотечких апликације су истовремено и њене предности. Навешћемо неке од њих: мобилне апликације састоје се од софтвера/скупа програма који се покреће на мобилном уређају и обављају одређене задатке за корисника; приступ одређеним ресурсима или услугама а да се претходно не мора отварати веб-прегледач; једноставност мобилне апликације: ${ }^{4}$ добре перформансе, као што су брзина апликације или учитавања страница; сигурност и безбедност корисника апликације; 5 подршка и ажурирања;

2 Андреа Катић, Симонида Вукадиновић и Сандра Брканли, „Примена мобилних апликација у образовању М - учење.” (Рад престављен на: XXIII Скуп трендови развоја: „Положај високог Образовања и науке у Србији.” Златибор, 22-24. 2. 2017), http://www.trend.uns.ac.rs/ stskup/trend_2017/radovi/T1.1/T1.1-6.pdf (преузето 30. 4. 2020).

3 Mishra, „Mobile App...”, 27.

4 Треба имати на уму да је главна карактеристика мобилне аппликације да се сваком садржају треба приступити на најједноставнији могући начин.

5 Није дозвољено пропуштање приватних података корисника. 
као и аналитика. ${ }^{6}$ Уколико су перформансе добре, то значи да корисник може лако приступити библиотечком каталогу; да више сати претражује базу без прекида; могућност да пита библиотекара за услугу; да добије информацију о доступности тражених публикација; обавести се о дешавањима у библиотеци итд. Све ове карактеристике спадају у предности коришћења мобилних апликација, а ту можемо додати да је већина тих апликација бесплатна, нема временског ограничења коришћења података, а и штеде употребу папира. А опет у недостатке спада и веродостојност података, величина екрана који умањује прегледност података, ограничена количина података и садржаја, а и то све повећава зависност од коришћења мобилних телефона.

\section{Врсте апликација}

Према мишљењу Јулије Бергман, ${ }^{7}$ постоје три врсте апликација: апликације за библиотечке каталоге које омогућују онлајн приступ; апликације за вредне фондове којима се омогућује приступ посебним деловима архива - попут ретких рукописа - и, коначно, апликације за проширену стварност у којима се комбинују информације из физичког света и онлајн подаци. Тако се, на пример, преко слике која долази из камере мобилног телефона добија додатни слој информација.

Осим тога, неопходно је направити разлику између интернет апликација и оних које се налазе у самом уређају, сматра Јулија Бергман. Ове последње се учитавају у мобилни уређај, за њихов рад није потребна интернет веза и оне користе постојеће функције паметног телефона или таблета: компас, ГПС, камеру, микрофон. Скоро све библиотечке апликације доступне су за оперативне системе који су најзаступљенији на тржишту: Apple (iOS) и Google (Андроид). ${ }^{8}$

Научне и јавне библиотеке често користе недовољно оптимизоване стандардне системе других пружалаца библиотечких услуга. Стога и апликације често личе једна на другу. Тек се мањи део може упоредити са

6 Ова функција омогућава праћење корисника и добијање потпуних информација о корисничким информацијама које траже. На основу тих информација можда ћете видети на који начин треба надоградити апликацију.

7 Инструкторка за информациону компетенцију која саветује библиотеке како да развијају своје дигиталне стратегије у Немачкој.

8 Patrick Wildermann, „Svet knjiga u pametnom telefonu. Aplikacije u bibliotekama”, https://www. goethe.de/ins/cs/sr/m/kul/mag/20446958.html/ (преузето 5. 5. 2020). 
каталошком апликацијом коју, на пример, нуди Њујоршка јавна библиотека, а која се по много чему сматра најбољом у овој области. Апликација NYPL Mobile9 тако садржи бар-код скенер помоћу којег се може проверити да ли се одређено дело заиста налази у фонду библиотеке. Затим, могућа је и позајмица електронских садржаја, слање обавештења о року враћања и управљање корисничким налогом. ${ }^{10}$

\section{Мобилне апликације у српским библиотекама}

За разлику од Европе и света, где скоро свака велика библиотека има своју мобилну апликацију, код нас су корисници углавном ускраћени за могућност коришћења библиотечких апликација. Што због лошег интернета, што због недостатка средстава, направљене апликације не могу да се унапређују и после извесног времена не функционишу. Такође, многе савремене мобилне апликације наши мобилни уређаји не могу да подрже. Након истраживања делатности библиотека у Србији, ауторка овог текста је утврдила да има неколико библиотечких апликација, од којих некима функције не могу да се унапреде и не функционишу. Позната је апликација „Библиотеке нашег окружења""11 која је последњи пут унапређена пре неколико година, али она више не функционише. Идеја ове апликације је да се увежу све библиотеке у Србији, тако да би се на једном месту могао пронаћи списак свих библиотека, као и могућност приступа њиховим садржајима. Власник ове апликације је Инйернети клуб, удружење стваралаца које повезују пословни интереси везани за заједнички успешнији наступ на глобалној рачунарској мрежи. Нажалост, сличан случај је и са мобилном апликацијом Библиотеке града Београда. ${ }^{12}$ Циљ ове апликације је да се помоћу ње корисници Библиотеке града Београда, на најбржи могући начин информишу о историјату саме библиотеке, о запосленима и о огранцима на територији града, затим да на лак и брз начин приступе каталогу и претраживању истог. Помоћу апликације могу лакше да приступе дигиталној библиотеци, као и информацијама о програмима који се свакодневно одржавају.

9 New York Public Library, https://browse.nypl.org/iii/mobile/ (преузето 5. 5. 2020).

10 Апликације у библиотекатма, https://www.bookvar.rs/aplikacije-u-bibliotekama/ (преузето 5. 5. 2020).

11 Библиотека нашег окружње, https://www.biblioteke.org.rs/ (преузето 1. 5. 2020).

12 Библиотека града Београда, https://play.google.com/store/apps/details?id=com.appmakr. bibliotekagradabeograda5 (преузето 5. 5. 2020). 
Градска библиотека Панчево је прва у Србији направила апликацију за мобилне телефоне која се такође може бесплатно скинути са интернета. ${ }^{13}$ Помоћу ње читаоци могу да претраже архиву публикација, као и друге информације о библиотеци. Нарочито интересантан део апликације је могућност читања кратког сижеа тражених књига. Међутим, ни ова апликација не функционише у целости. Може само да се приступи опису садржаја појединих издања публикација. А идеја је била да се омогући корисницима да без доласка у библиотеку провере доступност неке књиге.

Код нас извесно време постоји мобилна апликација која функционише, а то је $\mathrm{mCOBISS}^{14}$ у коју су укључене све библиотеке које су у COBISS систему. Фирма ИЗУМ је 1991. године промовисала систем COBISS (Кооперативни онлајн библиографски систем и сервиси) као надградњу система узајамне каталогизације. Тада је почео да се користи исти акроним и за припадајућу програмску опрему. Због распада Југославије, библиотеке ван Словеније су иступиле из заједничког система узајамне каталогизације, али постепено су скоро све обновиле сарадњу са ИЗУМ-ом и данас у својим државама изграђују аутономне библиотечко-информационе системе на платформи COBISS-a са узајамном каталогизацијом у мрежи COBISS.нет. ${ }^{15}$ Ова апликација омогућава коришћење сервиса Виртуелне библиотеке Србије на мобилним уређајима и служи за претраживање библиотечких електронских каталога и коришћење других услуга библиотеке посредством мобилних телефона и таблета.

Апликацију се може бесплатно преузети у „Рlay” продавници, а она, поред осталог, омогућује да се преко мобилних телефона и таблета претражује грађа у свим библиотекама чланицама COBISS.SR, такође се може стећи увид у стање задужења, продужити рок коришћења грађе, резервисати грађу, добијати е-обавештења, претраживати информације о библиотекама, приказ локације библиотеке на карти и смернице за пут до изабране библиотеке, чувати омиљене књиге на Мојој полици, очитавати ISBN и ISSN бар-кодове, и може да синхронизује корисничке профиле COBISS $^{16}$ и COBISS +.

13 Градска библиотека Панчево, https://www.biblioteka-pancevo.org.rs/mobilna-aplikacija-zapancevacku-biblioteku-video/ (преузето 5. 5. 2020).

14 mCOBISS, https://play.google.com/store/apps/details?id=si.izum.mcobiss\&hl=sr< (преузето 5 . 5. 2020).

15 Платформа COBISS, https://www.cobiss.net/sr/platforma-cobiss.htm (преузето 1. 5. 2020).

16 mCOBISS, https://m.cobiss.net/sr/default.htm\#home (преузето 11. 5. 2020). 


\section{Закључак}

У овом раду су наведене предности и могућности мобилних апликација у библиотекарству, карактеристике мобилне апликације са њеним предностима за библиотечки стручни кадар, али и за заједницу корисника. Такође је наведено неколико мобилних апликација код нас. Нажалост, већина не функционише. Употреба информационих и веб-технологија у већини библиотека у Србији је у различитим фазама развоја. Узрок томе је недовољно развијена инфраструктура, неадекватан софтвер, немогућност повезивања на интернет, као и недовољна информатичка писменост библиотечког особља. Ово су само неки од проблема са којима се сусрећу библиотеке у Србији. Али највећи проблем јесте и недостатак новчаних средстава за израду апликације, која није јефтина. Због тога и већина тих мобилних публикација не функционише, а то би у великој мери убрзало пословање и олакшало рад библиотекарима, а корисници би били много задовољнији.

Једино могуће решење може се видети у стратегији дигитализације која се у библиотекама Србије спроводи годинама уназад, и која ће подићи свест о коришћењу мобилних апликација у библиотечкој пракси. Апликације за мобилне телефоне нису сад најважније што једна библиотека треба да има, али са растућим тржиштем паметних телефона и таблета, и променама у начину живота који они доносе, мобилни развој постаје подручје које библиотечки стручни кадар не може занемарити. Мобилна решења постају део свакодневног живота већине људи, помажући им да се баве свакодневним задацима као што су проналажење информација, комуникација, куповина, прављење бележака подешавање аларма и фотографисање. Популарност паметних телефона и таблета расте, јер омогућавају корисницима да помоћу мобилне апликације уђу на сајт библиотеке и у библиотечку базу са „моћним” уређајем, са било ког места. А то у великој мери штеди време, како кориснику, тако и библиотекару.

Очекује се све више и више промена у области мобилне технологије следећих неколико година, као и њихова примена у библиотекама. Библиотекар мора у потпуности да разуме потенцијале мобилне технологије и њене употребе у библиотекама, јер се пружање квалитетне услуге заснива на складу са потребама корисника. 


\section{Literatura}

1. Biblioteka grada Beograda, https://play.google.com/store/apps/details?id=com. appmakr.bibliotekagradabeograda5 (preuzeto 5. 5. 2020).

2. Biblioteke našeg okruženja, https://www.biblioteke.org.rs (preuzeto 1. 5. 2020).

3. BookVar.Rs, „Aplikacije u bibliotekama”, https://www.bookvar.rs/aplikacije-u-bibliotekama/ (preuzeto 5. 5. 2020).

4. Gradska biblioteka Pančevo, „Biblioteka Pančevo”, https://www.biblioteka-pancevo. org.rs/mobilna-aplikacija-za-pancevacku-biblioteku-video/ (preuzeto 5. 5. 2020). (na ćirilici)

5. Katić, Andrea, Simonida Vukadinović i Sandra Brkanli. „Primena mobilnih aplikacija u obrazovanju M - učenje.” Rad predstavljen na XXIII Skup trendovi razvoja: „Položaj visokog Obrazovanja i nauke u Srbiji”, Zlatibor, 22-24. 2. 2017, http://www. trend.uns.ac.rs/stskup/trend_2017/radovi/T1.1/T1.1-6.pdf (preuzeto 30. 4. 2020). (na ćirilici)

6. Mishra, Ajay Shanker, Jai Krishna i Jha Sachin Kumar Umre. "Mobile App and the Library Services”. International Journal of Information Libraries \& Society, Vol. 6, Issue 1 (July 2017).

7. mCOBISS, https://m.cobiss.net/sr/default.htm\#home (преузето 11. 5. 2020).

8. mCOBISS, IZUM - Institut informacijskih znanosti, https://play.google.com/store/ apps/details?id=si.izum.mcobiss\&hl=sr< (преузето 5. 5. 2020).

9. New York Public Librars. "NYPL Mobile Catalog App”, https://browse.nypl.org/iii/ mobile/ (преузето 5. 5. 2020).

10. Platforma COBISS. COBISS - Kooperativni onlajn bibliografski sistem i servisi. https://www.cobiss.net/sr/platforma-cobiss.htm (преузето 1. 5. 2020).

11. Wildermann, Patrick. „Svet knjiga u pametnom telefonu. Aplikacije u bibliotekama”. https://www.goethe.de/ins/cs/sr/m/kul/mag/20446958.html/ (preuzeto 5. 5. 2020). 


\title{
Olivera D. Nastić
}

Belgrade City Library

olivera.nastic@gmail.com

\section{THE USAGE OF LIBRARY MOBILE APPLICATION}

\begin{abstract}
This paper provides a brief introduction to mobile technology applications and their use in library services. The paper also examines the types of mobile applications for librarians and highlights the specific applications available to librarians. Some prominent features of the applications are briefly described, as well as the advantages and the potential disadvantages. The author attempts to consider important issues such as security, reliability, availability, and cost, that library professionals must be aware of before using mobile applications. Library mobile applications, in addition to providing access to library collections, have some advanced features, such as lending books, searching archives, and others. It is also said that library mobile applications are "libraries that fit in your pocket". Unlike the libraries around the world, there are just a few libraries in Serbia that have developed a mobile application. This paper presents the expectations and possibilities of using library mobile applications in this country.
\end{abstract}

Keywords: technology, mobile phones, mobile applications, libraries, library services, books, publications.

Примљено: 11. маја 2020.

Исправке: 10. јуна 2020.

Прихваћено: 23. јуна 2020. 